\title{
Use of biocides for controlling viral diseases that attack common bean and cucumber plants
}

\author{
Ismail Mohamed Helal \\ Plant Researches Department \\ Nuclear Research Center, Atomic Energy Authority \\ P.N. 13759, Egypt
}

\begin{abstract}
This study aimed at investigating the antiviral activities of biocides made of formulated essential oils. These were derived from five plant species: fennel, oregano, peppermint, thyme and ginger. The potencies of these preparations were tested against local infection with the Tobacco necrosis virus (TNV) on common bean (Phaseolus vulgaris L.) and against systemic infection with the Cucumber mosaic virus (CMV) on cucumber (Cucumis sativus L.). After the determination of the most effective concentration, the formulated biocides were tested in protective and curative manners (before and after virus inoculation) against the growth of plants. The obtained results showed that the peppermint-derived biocide had the greatest effect on reducing the infectivity of the TNV virus (100\% growth inhibition at $4000 \mathrm{ppm}$ ), whereas the biocide from thyme was the most effective against the infectivity of the CMV virus, as it induced a complete growth inhibition at 3000 $\mathrm{ppm}$. The results of the protective and curative experiments revealed that the formulated biocides exerted high protection and curative effects against the two viruses. The observations revealed that the biocides were able to enhance plant defences against viral infection, as indicated by the increased levels of total chlorophyll, protein and phenols. Moreover, the levels of the oxidative stress markers including peroxidase (POD), polyphenol oxidase (PPO) and phenylalanine ammonia lyase (PAL) were improved compared to the control settings. In conclusion, the formulated biocides progressively present a favourable alternative to chemically synthesized pesticides in crop protection.
\end{abstract}

Key words: biochemical analysis, Cucumber mosaic virus, Cucumis sativus, essential oil, Phaseolus vulgaris, Tobacco necrosis virus

\section{Abbreviations:}

CMV - Cucumber mosaic virus, $\mathrm{FW}$ - fresh weight, hrs - hours, PAL - phenylalanine ammonia lyase, POD peroxidase, $\mathrm{PPO}$ - polyphenol oxidase, TMV - Tobacco mosaic virus, TNV - Tobacco necrosis virus, $\mathrm{V}$ - final volume

\section{INTRODUCTION}

Plant viruses are known to infect many crops, causing enormous losses in their production. On a large scale, the Tobacco necrosis virus (TNV) and Cucumber mosaic virus (CMV) are the main infectious agents among the current plant viruses that infect many plant species in different families. $\mathrm{Xi}$ et al. (2008) reported that TNV has a wide range as it infects monocotyledon, dicotyledon, herbaceous and woody plants (Zitikaite and Staniulis, 2009). Other reports have demonstrated 
that CMV is also widely distributed as it infects 1241 species segregated into 101 plant families. In cucumber (Cucumis sativus), it causes yellow mosaic and curling of the leaves, stunting of the plants, in addition to mosaic patterns on the fruits (Edwardson and Christie, 1991; Riedle-Bauer, 1998). The common bean (Phaseolus vulgaris L.) is considered as an important dietary protein, especially in developing countries. Also, the cucumber is one of the most important cultivated vegetables in the world. It is known to be among the best foods for one's overall health. Viral infections of these plants lead to a loss in their productivity.

Therefore, the control of viral diseases of these plants has a great importance in both protection and treatment protocols. Up till now, no chemical antivirals have been able to completely cure virusinfected plants. Their effect is limited to minimizing the pathogenic effects of viruses. This spurs many researchers to undertake alternative approaches through the employment of natural substances that may help in controlling viral diseases. Thus, many researchers have nominated essential oils and plant extracts as alternative natural, virus-controlling factors. Shukla et al. (1989), for instance, showed that essential oils of Pimpinella anisum and Foeniculum vulgare at 3000 ppm completely inhibited the formation of local lesions caused by the Potato X potexvirus, Tobacco mosaic virus or Tobacco ringspot nepovirus in the hypersensitive host of Chenopodium amaranticolor. Similarly, Bishop (1995) sprayed the essential oil of Melaleuca alternifolia onto plants of Nicotiana glutinosa before inoculating them with TMV. The essential oil treatment reduced the number of lesions for at least 10 days post-inoculation. Othman and Shoman (2004) reported that a Plectranthus tenuiflorus extract was tested against some viruses (such as TNV, TMV and Tomato spotted wilt virus). After being applied onto Chenopodium amaranticolor, Datura stramonium and Phaseolus vulgaris (in vivo), it minimized the infectivity of the above viruses by $77.7,85.8$ and $90.6 \%$, respectively. Mohamed (2010) found that an extract of onion and garlic clove stems controlled the potato disease caused by the Potato virus $Y$.

More recently, Min et al. (2013) found that essential oils extracted from lemon, ginger, tea tree, and others led to more than a 50\% inhibition of TMV at $100 \mu \mathrm{g} \mathrm{ml}^{-1}$. Moreover, essential oils of lemongrass and Artemisia showed both protective and curative effects and had a directly inhibiting effect on TMV infection. Jin et al. (2014) reported that TMV infection on Nicotiana tabacum 'Samsun' NN. plants was strongly inhibited by a leaf extract of Eupatorium adenophorum. Elsharkawy and El-Sawy (2015) found that the number of local lesions formed by the Bean common mosaic virus in bean plants was reduced by using extracts from Plectranthus tenuiflorus, Clerodendrum inerme, Schinus terebinthifolius, Azadirachta indica and Mirabilis jalapa plants. Petrov et al. (2016) showed that infections caused by the Potato virus $Y$ (PVY) and CMV on tomato plants were effectively controlled by an extract from Tanacetum vulgare.

The majority of previous trials were based on the application of unformulated essential oils extracted from different plant sources. This leads to limited applicability of using crude essential oils in plant protection apart from their limited stability resulting from their volatile nature and photodegradability. Previously, we formulated essential oil extracts, using natural carriers, to overcome the problem of their degradation and to maintain their effectiveness against bacteria and fungi (AboEl-Seoud et al., 2005). This formulation approach proved to enhance the effectiveness of formulated essential oils in both the protection and treatment of plant bacterial and fungal diseases (Helal and Abdeldaiem, 2008; Helal, 2017). The positive results had triggered our interest in mimicking this model in plant viral infections. Therefore, in the present work, we aimed to use liquid biocide formulations derived from fennel, peppermint, oregano, thyme and ginger essential oils to study their efficacy in the protection (prophylactic) and treatment of common bean and cucumber plants against viral diseases caused by TNV and CMV.

\section{MATERIAL AND METHODS}

\section{Plant materials}

Seeds of common bean (Phaseolus vulgaris L.) and cucumber (Cucumis sativus L.) were provided by Agricultural Research Institute, Dokki, Giza, Egypt. Clay pots of $40 \mathrm{~cm}$ diameter containing $2 \mathrm{~kg}$ of loamy soil were autoclaved three times at $1.5 \mathrm{~atm}$ for 30 minutes. The pots were seeded with common bean and cucumber seeds $(1 \mathrm{~cm}$ deep) at a rate of 10 seeds per pot and kept under natural daylight. The seeds and plants were watered regularly until the end of each experiment.

\section{Sources of viruses and inoculum preparation}

The viruses employed in this work were isolates of the Tobacco necrosis virus (TNV) and Cucumber mosaic virus (CMV). The viruses were kindly 
provided by the Department of Botany, Faculty of Science, Zagazig University, and by the Department of Agricultural Microbiology, Faculty of Agriculture, Ain Shams University, Cairo, Egypt, respectively. Viral inocula were prepared from infected fresh leaves of common bean (Phaseolus vulgaris L.) and cucumber (Cucumis sativus L.) previously infected with TNV and CMV, respectively. Following the procedure by Faccioli and Capponi (1983), five grams of common bean and cucumber leaves infected with TNV and CMV, respectively, were minced in the presence of $5 \mathrm{ml}$ of $0.01 \mathrm{M}$ phosphate buffer at $\mathrm{pH} 7.2$ (composed of $65 \mathrm{ml}$ of $0.05 \mathrm{M}$ $\mathrm{Na}_{2} \mathrm{HPO}_{4} \cdot 2 \mathrm{H}_{2} \mathrm{O} \mathrm{L}^{-1}$ and $35 \mathrm{ml}$ of $1 / 15 \mathrm{M} \mathrm{KH}_{2} \mathrm{PO}_{4}$ $\left.\mathrm{L}^{-1}\right)$ (Laurie, 1975) then filtered through Whatman filter paper No. 1 . The volume was brought up to 20 $\mathrm{ml}$ with the phosphate buffer ( $\mathrm{pH}$ 7.2). This dilution of extract helped to produce a suitable number of distinct local lesions and mosaic symptoms on the tested plants.

\section{Virus inoculation}

The primary leaves of common bean and cucumber plants were dusted with carborundum (600 mesh, Prolabo), then mechanically inoculated with the virus inoculum by using the index finger. The inoculated leaves were washed within 2 min. with distilled water. The infected leaves were kept frozen in a deep-freezer, and tested for viral activity. The frozen infected leaves were used as inocula in the present study, after being renewed every month.

\section{Biocide preparation}

Preparation of the biocides was carried out in the form of liquid formulations (emulsifiable concentrates) according to our previously described method (Abo-El-Seoud et al., 2005). In this regard, the essential oils were first mixed with different fixed oils individually in the proportion of 1:1 v/v. The mixture was then mixed with appropriate emulsifiers in a suitable proportion to form a clear stable emulsifiable concentrate.

\section{Antiviral activity assay of biocides}

The antiviral activities of the formulated biocides were investigated both in vitro and in vivo.

\section{In vitro antiviral screening assay of formulated} biocides

To assess the effect of formulated biocides on the viruses, solutions containing 1000, 2000, 3000, 4000 and $5000 \mathrm{ppm}$ of formulated essential oils in distilled water were prepared. They were mixed with equal volumes of virus inoculum (concentration, $20 \mu \mathrm{g} \mathrm{ml}^{-1}$ ), which was immediately used to inoculate the tested plants by gently rubbing the primary leaves previously dusted with 600 mesh carborundum as an abrasive. Healthy control plants were left without any treatments, viral control plants were inoculated with viruses only, whereas negative control plants were only treated with biocide solutions. All the treatments were made in triplicate (twenty plants each) on plants of a similar age and size grown in a greenhouse $\left(23^{\circ} \mathrm{C}, 16: 8 \mathrm{~h}\right.$ light/dark cycle). Local lesions caused by TNV on the inoculated common bean leaves lasted for 5-6 days after inoculation. Also, the mosaic symptoms caused by CMV on the inoculated cucumber plants continued for 20-days after inoculation.

The antiphytoviral inhibitory effect on the infectivity of the viruses was monitored according the formula:

$$
\mathrm{I} \%=\frac{C-T}{C} \times 100
$$

where: I\% - percent of inhibition; C (for TNV) mean No. of local lesions of viral control plants, $C$ (for CMV) - mean No. of inoculated plants; $\mathrm{T}$ (for TNV) - mean No. of local lesions of treated plants, $\mathrm{T}$ (for CMV) - mean No. of plants showing mosaic symptoms.

\section{In vivo antiviral assay of active formulated biocides}

The biocides that showed greater inhibition of viral infection during the in vitro experiment were further tested in vivo as follows:

A) Biocide treatment before inoculation (protective)

The ability of the validated biocide to protect common bean and cucumber plants against TNV or CMV infections was evaluated in vivo by using the method previously described by Chen et al. (2009), with some modifications. Briefly, $50 \mu 1$ of the $4000 \mathrm{ppm}$ solution of peppermint biocide was rubbed onto each primary leaf of common bean and the leaves were rubbed with carborundum $(600$ mesh). $50 \mu \mathrm{l}$ of $\mathrm{TNV}$ was then used to inoculate the biocide-treated leaves after 1, 6, 12, 24, 36, 48 and 72 hours of biocide treatment. The same method was repeated with cucumber leaves treated with the thyme biocide at a concentration of $3000 \mathrm{ppm}$ and then inoculated with CMV at the same intervals of time. All the treatments were carried out in triplicate (twenty plants each). The numbers of local lesions and mosaic symptoms were observed and recorded 5 and 20 days after infection with TNV and CMV, 
respectively. The percentage of inhibition of viral infectivity was calculated by using the equations given above for the in vitro experiment. Plants were harvested for biochemical analyses including total chlorophyll, total protein, total phenols, peroxidase (POD), polyphenol oxidase (PPO) and phenylalanine ammonia lyase (PAL).

B) Biocide treatment after inoculation (curative)

The curative effects of the validated biocides against $\mathrm{TNV}$ or CMV infections were investigated in vivo as described previously by Chen et al. (2009), with some modifications. The primary leaves were inoculated with $50 \mu \mathrm{l} /$ leaf of viral inoculum after dusting the leaves with carborundum (600 mesh), and then the leaves were washed with distilled water. The infected leaves were treated with the biocides under investigation (at a rate of $50 \mu 1 /$ leaf, with a $4000 \mathrm{ppm}$ solution of peppermint biocide applied on common bean and a $3000 \mathrm{ppm}$ solution of thyme biocide applied on cucumber) after 1, 6, 12, 24, 36, 48 and 72 hours of inoculation. Three replicates for each treatment were performed (twenty plants each). The number of local lesions and mosaic symptoms were observed and recorded 5 and 20 days after infection with TNV and $\mathrm{CMV}$, respectively. The percentage of inhibition was calculated and plants were harvested for the biochemical investigations listed above.

\section{Biochemical investigations}

For investigating the role of biocides in plant defense against infection, three enzymes - POD, PPO, and PAL, were assayed in leaf extracts. Also, total chlorophyll, phenol and protein contents were estimated.

\section{Estimation of total chlorophyll content}

Total chlorophyll was estimated in the leaves of healthy and virus-infected plants (controls), and in plants treated with biocides before or after 1 , $6,12,24,36,48$ and 72 hours of viral inoculation (protective and curative experiments). One gram of leaves was washed with distilled water, dried with filter paper and then ground with $80 \%$ acetone in a mortar and pestle. The volume of the ground mixture was adjusted to $10 \mathrm{ml}$ with $80 \%$ acetone, centrifuged at $2800 \mathrm{~g}$ for $10 \mathrm{~min}$., then the supernatant was recovered. The previous step was repeated with fresh $80 \%$ acetone until the pellet was clear. The absorbance of the supernatant was spectrophotometrically measured at 663 and $645 \mathrm{~nm}$ (Smith and Benitez, 1955). Three replicates were used for each treatment. Total chlorophyll
$\left(\mathrm{Chl}_{\text {tot }}\right.$ in $\left.\mathrm{mg} \mathrm{g}^{-1} \mathrm{FW}\right)$ content was calculated according to the formula:

$C h l_{\text {tot }}=20.2($ O.D. $) 645+8.02($ O.D. $) 663 \times \frac{V}{F W \times 1000}$

where: O.D. - optical density (nm); V - final volume of chlorophyll extract in $80 \%$ acetone $(\mathrm{mL}) ; \mathrm{FW}-$ fresh weight of the tissue extracted $(\mathrm{g})$.

\section{Estimation of total phenolics content}

The phenolics concentration was estimated according to Folin and Ciocalteu (1927). Briefly, one gram of plant material was ground in $5 \mathrm{ml}$ ethanol $(80 \%)$ and centrifuged at $2800 \mathrm{~g}$ for $10 \mathrm{~min}$. The extract was pooled and then made up to $10 \mathrm{ml}$ with $80 \%$ ethanol. $0.1 \mathrm{ml}$ of the extract was evaporated in a water bath and then $6 \mathrm{ml}$ of water was added before the addition of $0.5 \mathrm{ml}$ of the Folin-Ciocalteau reagent. After incubation for 5 in., $2 \mathrm{ml}$ of $20 \%$ sodium carbonate was added and the extract was incubated again for $30 \mathrm{~min}$. Then the absorbance was determined at $660 \mathrm{~nm}$. Three replicates were used for each sample.

\section{Estimation of total protein content}

Total protein was estimated colorimetrically by using the standard protocol according to the Bradford method (Bradford, 1976) at $595 \mathrm{~nm}$, where bovine serum albumin was used as a standard. The protein content in the leaves was recorded as $\mathrm{mg}$ of protein per $g$ of leaf. Each experiment was repeated three times.

\section{Enzyme extraction and assay}

In another context, the activities of the enzymes POD, PPO and PAL were determined in extracts of the leaves. The extraction was performed according to the method of Biles and Martyn (1993). In this method, one gram of leaves was ground in $2 \mathrm{ml}$ of a sodium phosphate buffer ( $\mathrm{pH}$ 6.5), transferred to test tubes, and then centrifuged at $16128 \mathrm{~g}$ at $4^{\circ} \mathrm{C}$ for $20 \mathrm{~min}$. All the enzyme activity measurements were performed in triplicate.

The activity of POD was assessed according to Hammerschmidt et al. (1982). In this method, 100 $\mu 1$ of leaf extract was added to $2.9 \mathrm{ml}$ of $100 \mathrm{mM}$ sodium phosphate buffer ( $\mathrm{pH}$ 6.5) containing $0.25 \%(\mathrm{v} / \mathrm{v})$ catechol and $100 \mathrm{mM} \mathrm{H}_{2} \mathrm{O}_{2}$. The absorbance was measured every $30 \mathrm{sec}$. for $3 \mathrm{~min}$. Enzyme activity was expressed as an increase in the absorbance per minute per gram of fresh weight. PPO activity was determined according to the method of Malik and Singh (1980) in which $100 \mu \mathrm{l}$ of leaf extract was added to $3 \mathrm{ml}$ of freshly prepared 
reaction mixture containing $0.01 \mathrm{M}$ of a buffered catechol solution ( $\mathrm{pH}$ 6.5). The absorbance was measured at $495 \mathrm{~nm}$ every 30 seconds for $3 \mathrm{~min}$. PPO activity is presented as the change in unit optical density (OD, at $495 \mathrm{~nm}$ ) $\mathrm{g}^{-1} \mathrm{FW} \mathrm{min}{ }^{-1}$.

The activity of PAL was measured in a fresh extract of leaves according to the described method of Solecka and Kacperska (2003), with some modifications. The extract was made by grinding $1 \mathrm{~g}$ of leaves in $2 \mathrm{ml}$ of $50 \mathrm{mM}$ borate buffer $(\mathrm{pH} 8.8)$ by using a mortar and pestle at $4^{\circ} \mathrm{C}$. The mixture was centrifuged at $16128 \mathrm{~g}$ for $10 \mathrm{~min}$. at $4^{\circ} \mathrm{C}$ and the supernatant was recovered and used for the determination of PAL activity. For deproteinization, the reaction mixture $(1 \mathrm{ml}$ of enzyme extract, $2 \mathrm{ml}$ of sodium borate buffer ( $\mathrm{pH} 8.8)$ and $1 \mathrm{ml}$ of $20 \mathrm{mM}$ L-phenylalanine) was incubated for $1 \mathrm{~h}$ at $30^{\circ} \mathrm{C}$; the reaction was stopped by adding $500 \mu 1$ of $6 \mathrm{NaHCl}$; the mixture was centrifuged at $16128 \mathrm{~g}$ for $10 \mathrm{~min}$., then the supernatant was used for the determination of enzyme activity. Enzyme activity was measured at $290 \mathrm{~nm}$ and expressed as $\mu \mathrm{mol}$ of trans-cinnamic acid formed per gram of fresh weight.

\section{Statistical analysis}

All the investigations were done in three replications. The results are presented as mean \pm standard deviation. Differences between means were determined by analysis of variance (ANOVA).

\section{RESULTS AND DISCUSSION}

\section{Effect of biocides on TNV and CMV infectivity}

In vitro assay

Different concentrations (1000, 2000, 3000, 4000 and $5000 \mathrm{ppm}$ ) of the formulated biocides (fennel, peppermint, oregano, thyme and ginger) were tested for their in vitro antiphytoviral activities against TNV and CMV infectivity on common bean and cucumber plants, respectively. In Table 1, the results showed that all the formulated biocides (with different concentrations) exhibited a significant inhibitory activity against TNV infection in vitro. It was observed that the peppermint biocide was the most effective in reducing the number of local lesions. It demonstrated the maximum inhibition of the infectivity of the virus, where a complete inhibition $(100 \%)$ was induced at concentrations of 4000 and $5000 \mathrm{ppm}$. In addition, the remaining formulated biocides demonstrated antiviral activities of different magnitudes. The in vitro effect of different concentrations of the five formulated biocides
Table 1. In vitro antiviral effect of formulated biocides on the infectivity of TNV on common bean plant

\begin{tabular}{|c|c|c|c|}
\hline Treatment & $\begin{array}{c}\text { Biocide } \\
\text { concentration }\end{array}$ & $\begin{array}{l}\text { Mean number } \\
\text { of local lesions }\end{array}$ & Mean I\% \\
\hline Healthy control & & $0.0 \pm 0.00$ & - \\
\hline Negative control & & $0.0 \pm 0.00$ & 0.0 \\
\hline Viral control & & $25.0 \pm 0.30$ & 0.0 \\
\hline \multirow{5}{*}{ Fennel } & 1000 & $19.1 \pm 1.05^{*}$ & 23.6 \\
\hline & 2000 & $13.8 \pm 0.87^{*}$ & 44.8 \\
\hline & 3000 & $12.5 \pm 0.78^{* *}$ & 50.0 \\
\hline & 4000 & $9.3 \pm 0.74 * *$ & 62.8 \\
\hline & 5000 & $7.5 \pm 0.87 * *$ & 70.0 \\
\hline \multirow{5}{*}{ Peppermint } & 1000 & $9.5 \pm 0.89 * *$ & 62.0 \\
\hline & 2000 & $7.5 \pm 0.87 * *$ & 70.0 \\
\hline & 3000 & $1.5 \pm 0.40 * *$ & 94.0 \\
\hline & 4000 & $0.0 \pm 0.00^{* *}$ & 100.0 \\
\hline & 5000 & $0.0 \pm 0.00^{* *}$ & 100.0 \\
\hline \multirow{5}{*}{ Oregano } & 1000 & $20.3 \pm 1.47 *$ & 18.8 \\
\hline & 2000 & $15.6 \pm 0.95^{*}$ & 37.6 \\
\hline & 3000 & $14.1 \pm 0.96^{*}$ & 43.6 \\
\hline & 4000 & $12.2 \pm 0.75^{* *}$ & 51.2 \\
\hline & 5000 & $9.4 \pm 0.81 * *$ & 62.4 \\
\hline \multirow{5}{*}{ Thyme } & 1000 & $14.7 \pm 0.95^{*}$ & 41.2 \\
\hline & 2000 & $13.4 \pm 0.72 *$ & 46.3 \\
\hline & 3000 & $10.9 \pm 0.96^{* *}$ & 56.4 \\
\hline & 4000 & $9.6 \pm 1.08^{* *}$ & 61.6 \\
\hline & 5000 & $7.8 \pm 0.80 * *$ & 68.8 \\
\hline \multirow{5}{*}{ Ginger } & 1000 & $15.0 \pm 0.95^{*}$ & 40.0 \\
\hline & 2000 & $11.6 \pm 0.80^{* *}$ & 53.6 \\
\hline & 3000 & $5.6 \pm 0.72 * *$ & 77.6 \\
\hline & 4000 & $3.1 \pm 0.44 * *$ & 87.6 \\
\hline & 5000 & $1.8 \pm 0.35^{* *}$ & 92.8 \\
\hline
\end{tabular}

*** indicate significant and highly significant reduction in disease compared with viral control

against CMV on cucumber is presented in Table 2. Clearly, all the formulated biocides (with different concentrations) induced a significant inhibition against CMV infectivity. The maximum inhibition was produced by applying the thyme biocide, where it gave a complete inhibition (100\%) at concentrations of 3000,4000 and $5000 \mathrm{ppm}$. Other biocides significantly reduced the infectivity of the virus used for inoculation, but to a lesser extent compared with the thyme biocide. These findings are similar to the results obtained by Min et al. (2013) and Dunkić et al. (2013). Thus, the inhibition of infectivity could be attributed to the potential of biocides to prevent TNV and CMV replications by dissolving or penetrating the virus coat and denaturation of their proteins and nucleic acids (Othman and Shoman, 
Table 2. In vitro antiviral effect of formulated biocides on the infectivity of CMV on cucumber plant

\begin{tabular}{|c|c|c|c|}
\hline Treatment & $\begin{array}{c}\text { Biocide } \\
\text { concentration }\end{array}$ & $\mathrm{T}$ & Mean I\% \\
\hline Healthy control & & $0.0 \pm 0.00$ & - \\
\hline Negative control & & $0.0 \pm 0.00$ & 0.0 \\
\hline Viral control & & $20.0 \pm 0.00$ & 0.0 \\
\hline \multirow{5}{*}{ Fennel } & 1000 & $14.0 \pm 0.90^{*}$ & 30 \\
\hline & 2000 & $8.0 \pm 0.92 * *$ & 60 \\
\hline & 3000 & $3.0 \pm 0.60 * *$ & 85 \\
\hline & 4000 & $2.0 \pm 0.30 * *$ & 90 \\
\hline & 5000 & $1.0 \pm 0.31 * *$ & 95 \\
\hline \multirow{5}{*}{ Peppermint } & 1000 & $7.0 \pm 0.61 * *$ & 65 \\
\hline & 2000 & $6.0 \pm 0.53^{* *}$ & 70 \\
\hline & 3000 & $5.0 \pm 0.44 * *$ & 75 \\
\hline & 4000 & $2.0 \pm 0.40 * *$ & 90 \\
\hline & 5000 & $1.0 \pm 0.36^{* *}$ & 95 \\
\hline \multirow{5}{*}{ Oregano } & 1000 & $13.0 \pm 0.85^{*}$ & 35 \\
\hline & 2000 & $10.0 \pm 0.61 * *$ & 50 \\
\hline & 3000 & $7.0 \pm 0.70 * *$ & 65 \\
\hline & 4000 & $5.0 \pm 0.75^{* *}$ & 75 \\
\hline & 5000 & $4.0 \pm 0.50 * *$ & 80 \\
\hline \multirow{5}{*}{ Thyme } & 1000 & $6.0 \pm 0.70^{* *}$ & 70 \\
\hline & 2000 & $2.0 \pm 0.36^{* *}$ & 90 \\
\hline & 3000 & $0.0 \pm 0.00 * *$ & 100 \\
\hline & 4000 & $0.0 \pm 0.00 * *$ & 100 \\
\hline & 5000 & $0.0 \pm 0.00 * *$ & 100 \\
\hline \multirow{5}{*}{ Ginger } & 1000 & $12.0 \pm 0.87^{*}$ & 40 \\
\hline & 2000 & $9.0 \pm 0.90 * *$ & 55 \\
\hline & 3000 & $8.0 \pm 0.79 * *$ & 60 \\
\hline & 4000 & $8.0 \pm 0.70 * *$ & 60 \\
\hline & 5000 & $5.0 \pm 0.55^{* *}$ & 75 \\
\hline
\end{tabular}

$\mathrm{T}$ - the mean No. of treated plants showing mosaic symptoms $*$,** indicate significant, highly significant reduction in viral disease compared with viral control

2004; Kobeasy et al., 2013). The differences in the antiviral activities of different biocides may be attributed to the compositional diversity of the active ingredients of the essential oils, structural diversity of their antimicrobial components, and the relative concentrations of the active components they contain (Min et al., 2013).

\section{In vivo assay (protective and curative)}

Table 3 shows the protective and curative effects of the peppermint biocide against TNV infection. The obtained data revealed that the tested biocide exhibited high levels of inhibitory effects against TNV in the experimental plant at all-time points when treated before or after inoculation (protective and curative). The highest protective and curative effects were obtained by applying the biocide at the interval of $24 \mathrm{hrs}$, before or after virus infection. In addition, the data in Table 4 represents the protective and curative potential of the thyme biocide with a concentration of $3000 \mathrm{ppm}$ for cucumber plants against CMV infectivity. The results showed a significant inhibition of CMV infectivity at all time points when applied in a rotective and curative manner. The maximum protection and inhibition percentage observed 24 hrs before and after application were 91.5\% and $83.5 \%$, respectively. These results agree with those of Dunkić et al. (2013) as they reported that treating Chenopodium quinoa plants with both Eryngium amethystinum and E. alpinum essential oils prior

Table 3. Protective and curative effects of the biocide of peppermint oil (4000 ppm) for common bean plants against TNV infectivity at different times of treatment

\begin{tabular}{lcccc}
\hline \multirow{2}{*}{$\begin{array}{l}\text { Time of } \\
\text { treatment } \\
\text { (hrs) }\end{array}$} & Protective capacity & \multicolumn{2}{c}{ Curative capacity } \\
& $\mathrm{T}$ & $\mathrm{I} \%$ & $\mathrm{~T}$ & $\mathrm{I} \%$ \\
\hline 1 & $3.5 \pm 0.53^{* *}$ & 86.0 & $4.7 \pm 0.89^{* *}$ & 81.2 \\
6 & $3.2 \pm 0.62^{* *}$ & 87.2 & $4.5 \pm 0.53^{* *}$ & 82.0 \\
12 & $1.1 \pm 0.40^{* *}$ & 95.6 & $3.8 \pm 0.56^{* *}$ & 84.8 \\
24 & $1.0 \pm 0.26^{* *}$ & 96.0 & $3.7 \pm 0.62^{* *}$ & 85.2 \\
36 & $2.0 \pm 0.46^{* *}$ & 92.0 & $3.9 \pm 0.66^{* *}$ & 84.4 \\
48 & $3.6 \pm 0.60^{* *}$ & 85.6 & $4.8 \pm 0.72^{* *}$ & 80.8 \\
72 & $3.8 \pm 0.62^{* *}$ & 84.8 & $5.2 \pm 0.75^{* *}$ & 79.2 \\
\hline
\end{tabular}

I \% - percent of inhibition

$\mathrm{T}$ - the mean No. of treated plants showing mosaic symptoms. ** highly significant reduction in disease compared with viral control

Table 4. Protective and curative effects of the biocide of thyme oil (3000 ppm) for cucumber plants against CMV infectivity at different times of treatment

\begin{tabular}{lcccc}
\hline \multirow{2}{*}{$\begin{array}{l}\text { Time of } \\
\text { treatment } \\
\text { (hrs) }\end{array}$} & Protective capacity & \multicolumn{2}{c}{ Curative capacity } \\
& $\mathrm{T}$ & $\mathrm{I} \%$ & $\mathrm{~T}$ & $\mathrm{I}^{\%}$ \\
\hline 1 & $3.5 \pm 0.50^{* *}$ & 82.5 & $4.5 \pm 0.87^{* *}$ & 77.5 \\
6 & $3.3 \pm 0.76^{* *}$ & 83.5 & $4.2 \pm 0.58^{* *}$ & 79.0 \\
12 & $3.0 \pm 0.50^{* *}$ & 85.0 & $3.7 \pm 0.29^{* *}$ & 81.5 \\
24 & $1.7 \pm 0.29^{* *}$ & 91.5 & $3.3 \pm 0.76^{* *}$ & 83.5 \\
36 & $3.2 \pm 0.58^{* *}$ & 84.0 & $3.5 \pm 0.50^{* *}$ & 82.5 \\
48 & $3.5 \pm 0.87^{* *}$ & 82.5 & $4.0 \pm 1.00^{* *}$ & 80.0 \\
72 & $4.1 \pm 0.76^{* *}$ & 79.0 & $5.0 \pm 1.32^{* *}$ & 75.0 \\
\hline
\end{tabular}

$\mathrm{I} \%$ - percent of inhibition

$\mathrm{T}$ - the mean No. of treated plants showing mosaic symptoms.

** highly significant reduction in disease compared with viral control 
to inoculation with CMV significantly reduced the number of lesions, with inhibition rates of 80.5 and $77.8 \%$, respectively. The antiviral effect of biocides appears to involve direct inhibition of virus replication, or indirectly through inducing systemic resistance of the host plant against the virus, which may persist for long periods depending on both plant cultivar and the virus strain (Othman and Shoman, 2004; Mahdy et al., 2007; Waziri, 2015).

In general, the data presented in Table 3 and 4 indicated that a better inhibitory effect of the investigated biocides was obtained by preinoculation (protective) treatment than the postinoculation (curative) one.

\section{Biochemical investigations}

The present study also included the investigation of some biochemical markers in common bean and cucumber plants. These investigations were performed on biocide-treated plants either before or after viral infections (Figs 1 and 2).
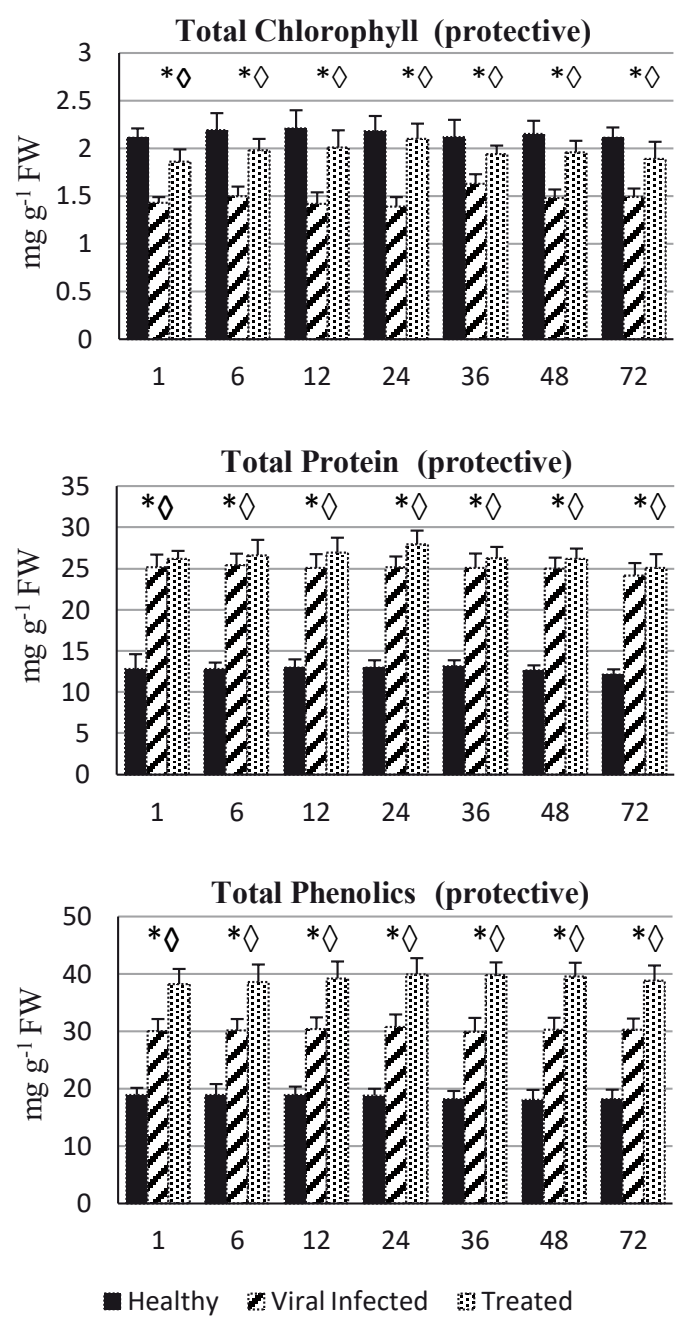

In common bean (Figs 1a and $1 b$ ), virus infection caused a marked reduction in total chlorophyll and protein contents compared to their levels in healthy control plants. Treatment of plants with the peppermint-derived biocide (protectively and curatively) resulted in a marked increase in total chlorophyll and protein concentrations, but they remained lower than those of healthy control plants. The maximum concentrations of total chlorophyll and protein were measured 24 hrs after the biocide treatment in both protective and curative experiments. The same results had been obtained by Anuradha et al. (2015) and Mofunanya and Edu (2015). The reduction in the chlorophyll content in virus-infected plants may be due to the stimulation of some cellular enzymes like chlorophyllase (Goodman et al., 1967), or as a consequence of the effect of the virus on pigment synthesis (Balachandran et al., 1997). The common bean plants treated with the peppermint biocide showed an improvement in chlorophyll content,
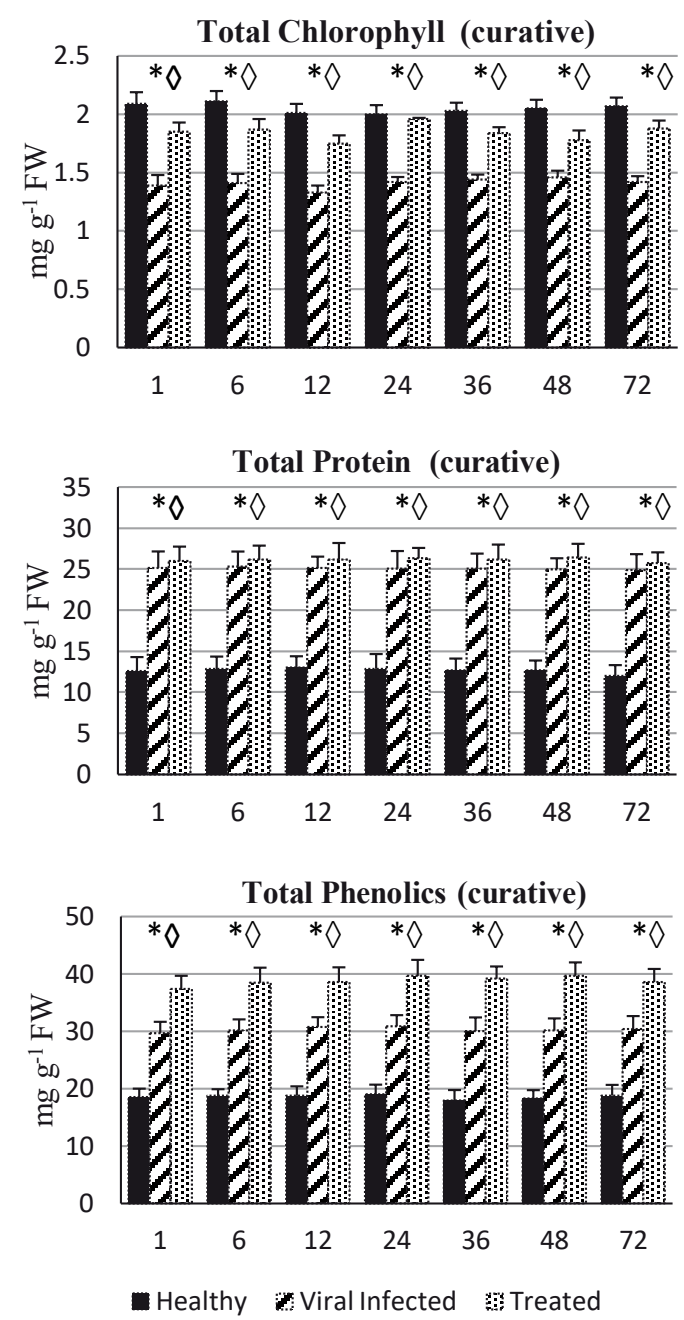

Figure 1a. Protective and curative effects of peppermint biocide treatment on the biochemical contents of common bean plants inoculated with TNV at different time intervals (hours) - changes in total chlorophyll, protein and phenol contents 


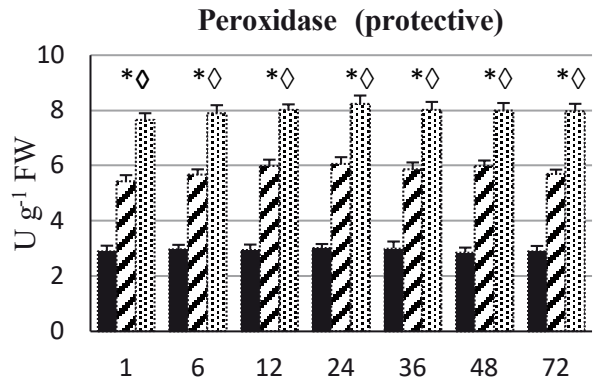

Polyphenol oxidase (protective)

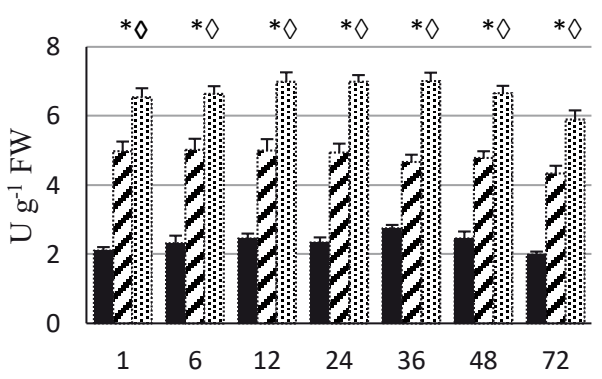

Phenylalanine ammonia-lyase (protective)

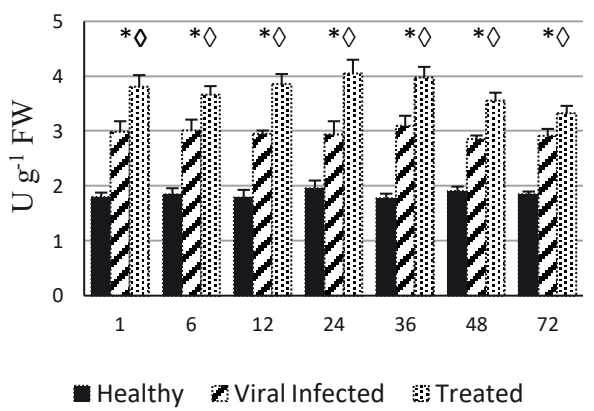

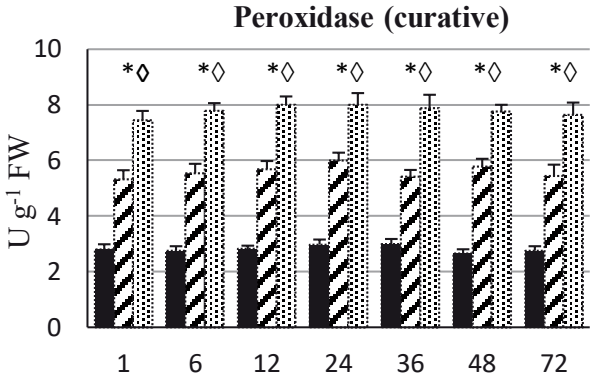

Polyphenol oxidase (curative)

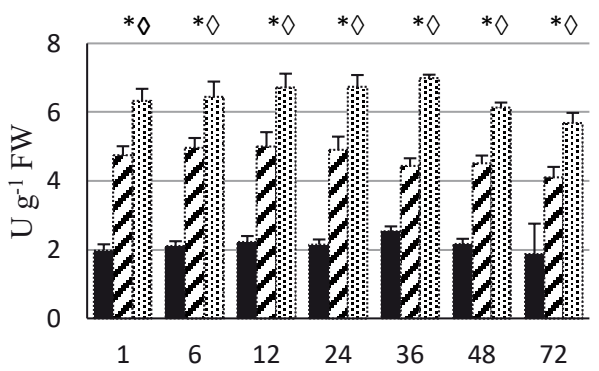

Phenylalanine ammonia-lyase (curative)

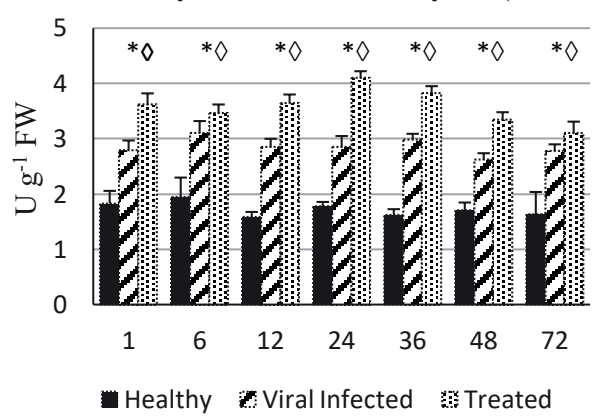

Figure 1b. Protective and curative effects of peppermint biocide treatment on the biochemical contents of common bean plants inoculated with TNV at different time intervals (hours) - changing in peroxidase, polyphenol oxidase and phenylalanine ammonia-lyase activities

indicating that the biocide can destroy the virus, thereby enhancing the host's resistance to disease. On the other hand, the chlorophyll content of common bean leaves treated with the biocide in each treatment period was found to be lower than in the healthy control, indicating that the peppermint biocide may not be able to completely suppress damaging of the chloroplast by the virus (Fan et al., 2011). The increase in protein concentration in virus-infected plants may be explained by the enhanced activity of RNA polymerase or RNA synthetase and the formation of new antiviral proteins (Rao et al., 1989).

The phenolic content increased in the inoculated (viral control) plants compared to the corresponding levels of the healthy control plants. Also, treating common bean plants with the biocide increased the phenolic content above that of healthy and virusinfected plants during the protective and curative experiments. The observations summarized in
Figure 1a demonstrated that the total phenolics concentration was higher in the infected common bean plants than in the corresponding healthy plants. Also, when the peppermint biocide was applied as a protective or curative agent, the total phenolics content of the treated plants significantly increased to higher levels compared to healthy and virus-infected plants. These results are in agreement with those of Kofalvi and Nassuth (1995), who reported a significant increase in the phenolics content in wheat infected with the Wheat streak mosaic potyvirus. Upon infection by viruses and treatment with biocides, the higher concentration of phenolic compounds in the host plants could contribute to enhancing the strength of the host cell walls by the synthesis of lignin and suberin known to be involved in the formation of physical barriers against the spread of pathogens (Singh et al., 2014; Anuradha et al., 2015). In addition, Reimers and Leach (1991) and Abdel-Shafi (2013) 


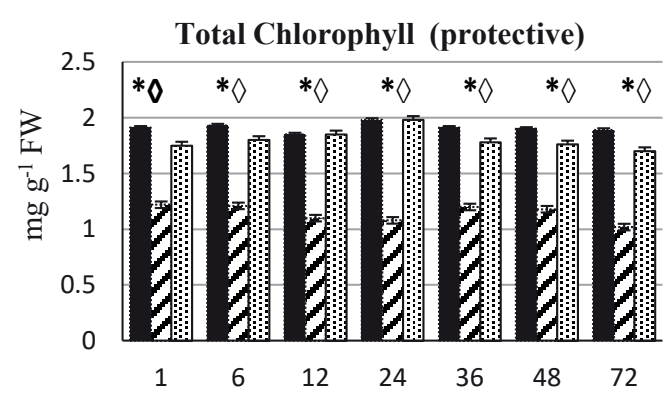

Total Protein (protective)
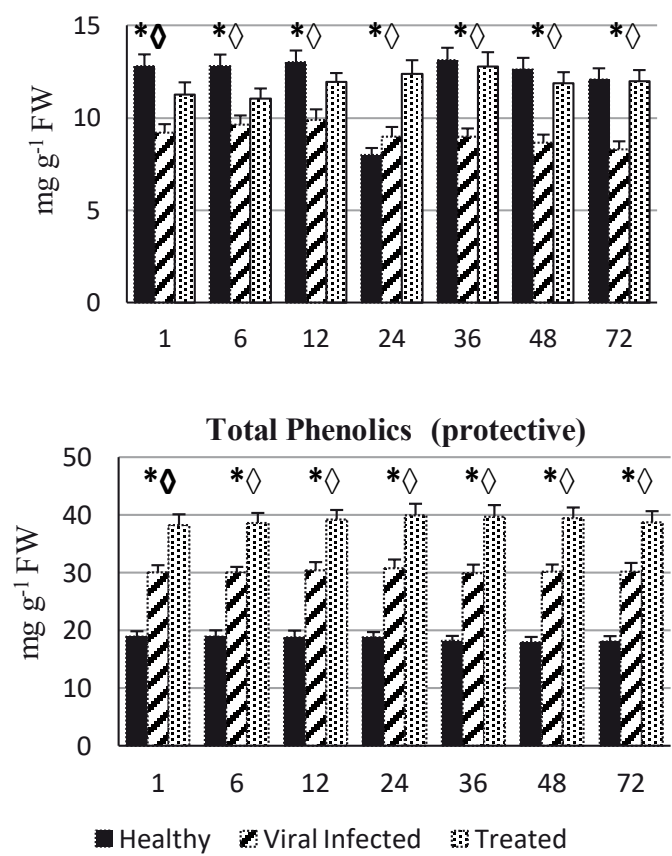

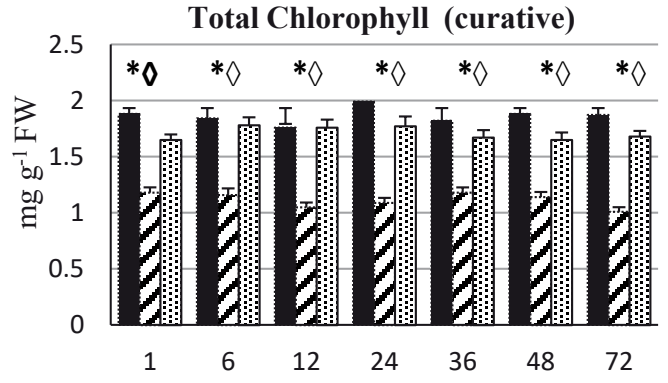

Total Protein (curative)
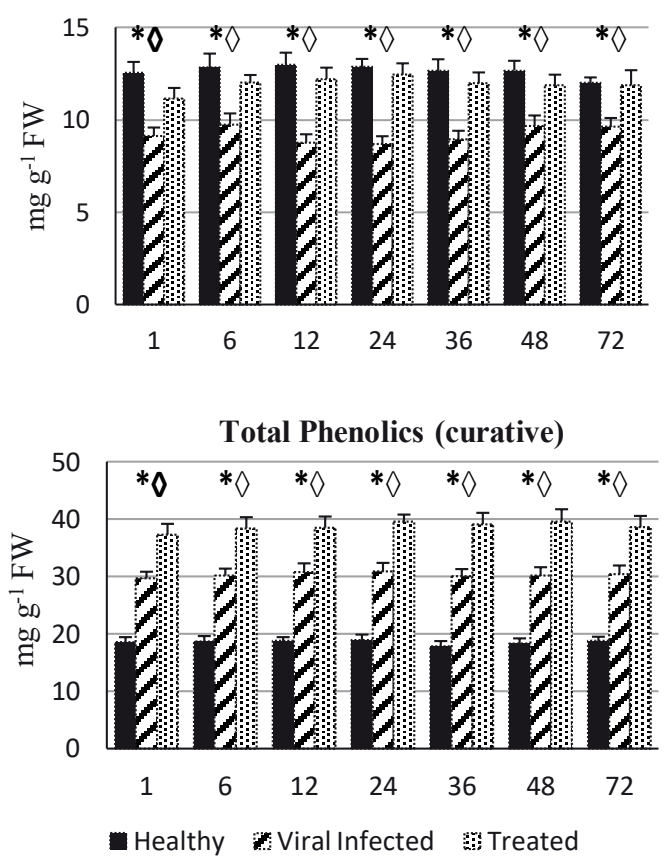

Figure 2a. Protective and curative effects of thyme biocide treatment on the biochemical contents of cucumber plants inoculated with CMV at different time intervals (hours) - changes in total chlorophyll, protein and phenol contents

reported that high levels of phenolic compounds around an infected area can weaken or restrict pathogen growth. The increase in the concentration of phenolic compounds in common bean plants by treatments with biocide after challenging them with TNV in the present study may be due to the activation of the hexose-monophosphate pathway and/or the acetate pathway, and release of bound phenolics by hydrolytic enzymes. (El-Shazly and Abd El-Wahab, 2017).

The defense-related enzymes POD, PPO and PAL are generally considered to be important in promoting host resistance because they are able to catalyze the last step of lignin biosynthesis (Hammerschmidt et al., 1982) and may oxidize phenolic compounds to quinones (Campos-Vargas and Saltveit, 2002), and these quinones are toxic to the virus (Wang et al., 2009). Therefore, the resistance markers: POD, PPO and PAL were extracted from common bean plants and their specific activities were determined. The data shown in Figure $1 b$ indicates that TNV infection increased the activities of these enzymes compared to those of healthy plants, whereas the treatments with the peppermint biocide (protectively and curatively) increased the enzyme activities more than in virusinfected plants. A similar increase in POD and PPO was observed by Anuradha et al. (2015) in banana plants.

Also, the data in Figures $2 \mathrm{a}$ and $2 \mathrm{~b}$ demonstrate the biochemical changes in cucumber plants as being affected by biocide application and viral infection. The results revealed a drastic reduction in the total chlorophyll and protein contents in virus-infected cucumber compared to the normal levels observed in healthy plants. On the other hand, a significant increase was observed in both the total chlorophyll and protein in the plants treated with the thyme biocide in protective and curative manners. Also, the phenolics content increased in virus-infected plants compared to that of healthy ones. The treatment with the 


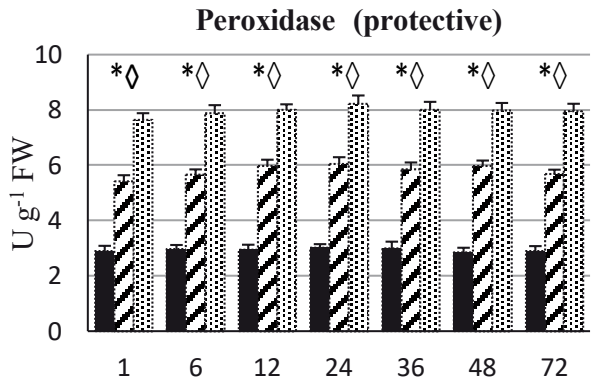

Polyphenol oxidase (protective)

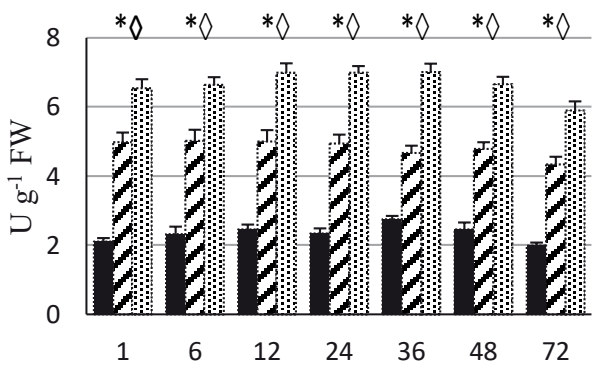

Phenylalanine ammonia-lyase (protective)

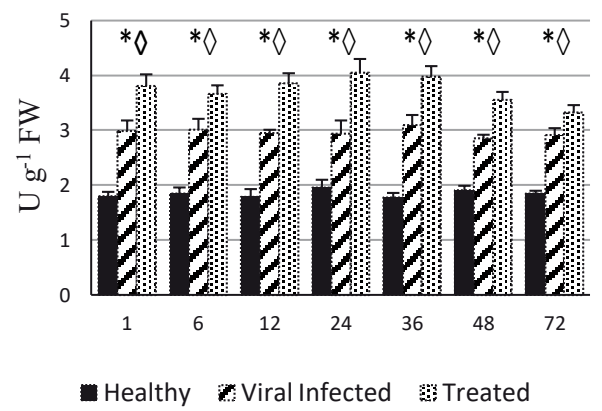

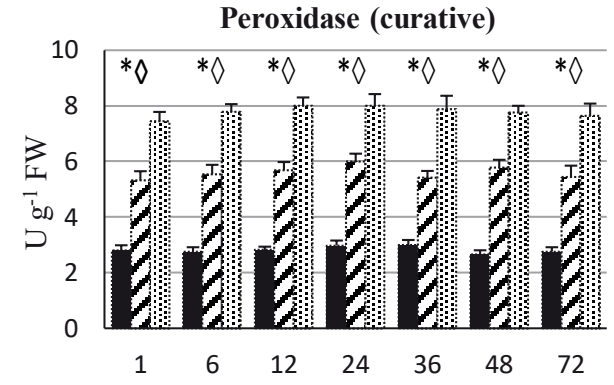

Polyphenol oxidase (curative)

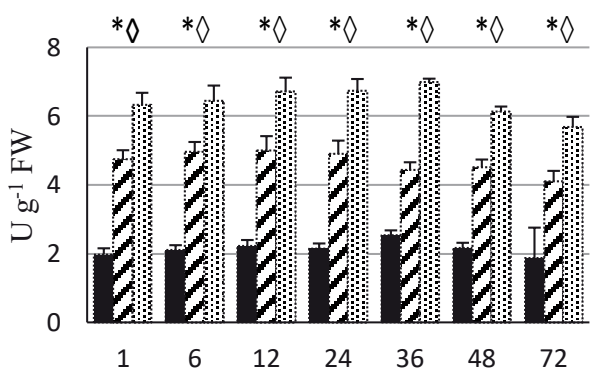

Phenylalanine ammonia-lyase (curative)

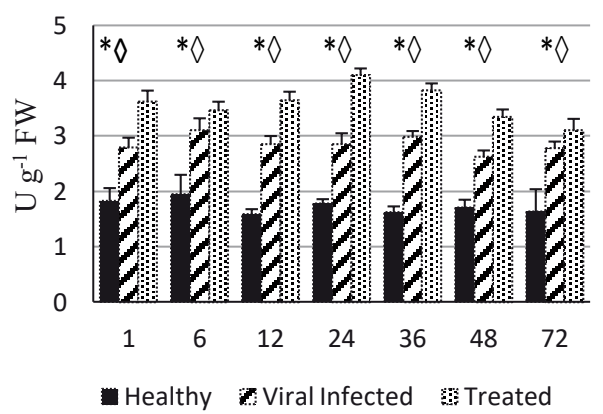

Figure 2b. Protective and curative effects of thyme biocide treatment on the biochemical contents of cucumber plants inoculated with CMV at different time intervals (hours) - changes in peroxidase, polyphenol oxidase and phenylalanine ammonia-lyase activities

thyme-derived biocide led to a two-fold increase in phenolics content compared to that of healthy plants. These results are in agreement with those of Abdel-Shafi (2013), who reported that squash plants infected with the Zucchini yellow mosaic virus showed elevated levels of both total phenolics and protein compared to uninfected control plants. However, there was a gradual increase in these contents in plants treated with a Nigella sativa seed extract. By contrast, cucumber plants treated with the thyme biocide showed a significant increase of $100 \%$ and $200 \%$ more in POD, PPO and PAL activities than in those of virus-infected and healthy plants, respectively, at all time points. In this regard, Mofunanya et al. (2016) had found significant increases in the activities of the oxidative enzymes in Telfairia occidentalis plants as a result of infection with the Telfairia mosaic virus compared to their corresponding healthy controls at all post-inoculation times. In addition,
Zhao et al. (2017) found that the activities of POD and PAL were higher in tobacco plants treated with oleic-acid than in those inoculated with the Tobacco mosaic virus and water-treated tobacco. The results show that the plant responds to viral infection by activating several enzymes of the antioxidant system and hence the intensification in the activity of some defence related to these enzymes. In fact, the increment in POD, PPO and PAL contents in biocide-treated plants compared with those of virus-infected ones may be due to increased specific defence gene expression leading to the activation of an enzyme or group of defence enzymes downstream (Kobeasy et al., 2013)

\section{CONCLUSIONS}

In conclusion, the formulated biocides of peppermint and thyme oils could be successfully used as natural biocides for controlling local and 
systemic plant viral diseases on common bean and cucumber plants.

\section{ACKNOWLEDGEMENTS}

I would like to express my complete gratefulness to the experimental farm members of the Plant Researches Department, Nuclear Research Center, Atomic Energy Authority, Egypt, for their technical assistance.

\section{FUNDING}

Nuclear Research Center, Atomic Energy Authority, Egypt.

\section{CONFLICT OF INTEREST}

The author declares no conflict of interest.

\section{REFERENCES}

Abdel-Shafi S., 2013. Preliminary studies on antibacterial and antiviral activities of five medicinal plants. J. Plant. Pathol. Microb. 4, 190.

Abo-El Seoud M.A., Sarhan M.M., Omar A.E., Helal M.M., 2005. Biocides formulation of essential oils having antimicrobial activity. Arch. Phytopathol. Plant Protect. 38(3), 175-184.

Anuradha C., Selvarajan R., Vasantha S., Suresha G.S., 2015. Biochemical characterization of compatible plant virus interaction: A case study with bunchy top virus-banana host-pathosystem. Plant Pathol. J. 14(4), 212-222.

Balachandran S., Hurry V.M., Kelley S.E., Osmond C.B., Robinson S.A., Rohozinski J., ET AL., 1997. Concepts of plant biotic stress. Some insights into the stress physiology of virus-infected plants, from the perspective of photosynthesis. Physiol. Plant. 100, 203-213.

Biles C.L., Martyn R.D., 1993. Peroxidase, polyphenoloxidase, and shikimate dehydrogenase isozymes in relation to the tissue type, maturity and pathogen induction of watermelon seedlings. Plant Physiol. Biochem. 31, 499-506.

Bishop C.D., 1995. Antiviral activity of the essential oil of Melaleuca alternifolia (Maiden and Betche) Cheel (tea tree) against Tobacco mosaic virus. J. Essent. Oil Res. 7, 641-644.

BRADFORD M.M., 1976. A rapid and sensitive method for the quantitation of microgram quantities of protein utilizing the principle of protein-dye binding. Anal. Biochem. 72, 248-254.

Campos-Vargas R., Saltveit M.E., 2002. Involvement of putative chemical wound signals in the induction of phenolic metabolism in wounded lettuce. Physiol. Plant. 114, 73-84.

Chen J., Yan X.-H., Dong J.-H., Sang P., Fang X., Di Y.-T., ET AL., 2009. Tobacco mosaic virus (TMV) inhibitors from Picrasma quassioides Benn. J. Agric. Food Chem. 57, 6590-6595.

Dunkić V., Vuko E., Bezić N., Kremer D., Ruscić M., 2013. Composition and antiviral activity of the essential oils of Eryngium alpinum and E. amethystinum. Chem. Biodivers. 10, 1894-1902.

Edwardson J.R., Christie R.G., 1991. Cucumoviruses. In: Handbook of Viruses Infecting Legumes. J.R. Edwardson (Ed.), CRC Press, Boca Raton, USA, 294-303.

Elsharkawy M.M., El-Sawy M.M., 2015. Control of Bean common mosaic virus by plant extracts in bean plants. Int. J. Pest Manage. 61(1), 54-59.

El-Shazly M.A., AbD El-Wahab A.S., 2017. Effect of jojoba seed extract and riboflavin in preventing the transmission of Iris yellow spot virus (IYSV): Tospovirus by Thrips tabaci L. to onion plants in Egypt. Int. J. Virol. 13, 14-28.

FACCIOLI G., CAPPONI R., 1983. An antiviral factor present in plants of Chenopodium amaranticolor locally infected by Tobacco necrosis virus: 1 . Extraction, partial purification, biological and chemical properties, J. Phytopathol. 106(4), 289-301.

Fan H.T., Song B.A., Bhadury P.S., Jin L.H., Hu D.Y., YANG S., 2011. Antiviral activity and mechanism of action of novel thiourea containing chiral phosphonate on Tobacco mosaic virus. Int. J. Mol. Sci. 12, 4522-4535.

Folin O., Ciocalteu V., 1927. On tyrosine and tryptophane determinations in proteins. J. Biol. Chem. 73, 627-650.

Goodman R.N., Kiraly Z., Zaitlin M., 1967. The Biochemistry and Physiology of Infectious Plant Diseases. D. Van Nostrand Co. Inc., Princeton, New Jersey, USA.

Hammerschmidt R., Nuckles E.M., KuC J., 1982. Association of enhanced peroxidase activity with induced systemic resistance of cucumber to Colletotrichum lagenarium. Physiol. Plant Pathol. 20, 73-76.

Helal I.M., 2017. Control of damping-off disease in some plants using environmentally safe biocides. Pak. J. Bot. 49(1), 361-370.

Helal I.M.M., AbDeldaiem M. H., 2008. Control of black rot disease of tomato fruits using formulated ginger essential oil treated by gamma radiation. Proc. $9^{\text {th }}$ International Conference of Nuclear Sciences and Applications, 11-14 Feb 2008 Sharm El-Shiekh - Sinai - Egypt.

Jin Y., Hou L., Zhang M., Tian Z., CaO A., Xie X., 2014. Antiviral activity of Eupatorium adenophorum leaf extract against Tobacco mosaic virus. Crop Prot. 60, 28-33.

Kobeasy M.I., EL-Shazly M.A., Rashed M.M., YouseF R.S., 2013. Antiviral action of lavender (Lavendular vera) essential oil against Tomato spotted wilt virus infected tomato plant. J. Chem. Acta 2, 53-60. 
Kofalvi S.A., NASSUth A., 1995. Influence of Wheat streak mosaic virus infection on phenylpropanoid metabolism and the accumulation of phenolics and lignin in wheat. Physiol. Mol. Plant Pathol. 47, 365377.

LAURIE J., 1975. Handbook of Analytical Chemistry. Mir Publishers, Moscow, Russia.

Mahdy A.M.M., Fawzy R.N., Hafez M.A., Mohamed H.A.N., Shahwan E.S.M., 2007. Inducing systemic resistance against Bean yellow mosaic potyvirus using botanical extracts. Egyptian J. Virol. 4, 129145.

Malik C.P., Singh M.B., 1980. Plant enzymology and histoenzymology. Kalyani Publishers, New Delhi, India.

Min L., Han Z., Xu Y., Yao L., 2013. In vitro and in vivo anti-Tobacco mosaic virus activities of essential oils and individual compounds. J. Microbiol. Biotechnol. 23(6), 771-778.

MofunAnya A.A.J., Edu E.A., 2015. Physiological and biochemical changes in Cucurbita moschata Duch. Ex. Poir inoculated with a Nigerian strain of Moroccan Watermelon mosaic virus (MWMV): Lagenaria breviflora isolate. Int. J. Plant Pathol. 6(2), 36-47.

Mofunanya A.A.J., Owolabi A.T., Nkang A., 2016. Time course evaluation of the activities of some enzymes in Telfairia mosaic virus infected ecotypes of Telfairia occidentalis Hook f. Plant Pathol. J. 15, 86-94.

MoHamed E.F., 2010. Antiviral properties of garlic cloves juice compared with onion bulbs juice against Potato virus Y (PVY). J. Am. Sci. 6(8), 302-310.

Othman B.A., Shoman S.A., 2004. Antiphytoviral activity of the Plectranthus tenuiflorus on some important viruses. Int. J. Agric. Biol. 6, 844-849.

Petrov N., Stoyanova M., Valkova M., 2016. Antiviral activity of plant extract from Tanacetum vulgare against Cucumber mosaic virus and Potato virus $Y$. J. BioSci. Biotechnol. 5(2), 189-194.

Rao G., Ghosal M., Shukla K., 1989. Comparative study of carbohydrate and protein content of Radish mosaic virus infected, inhibitor treated and healthy radish plants. Indian J. Virol. 5, 123-126.
Reimers P., LeAch J., 1991. Race-specific resistance to Xanthomonas oryzae pv. oryzae conferred by bacterial blight resistance gene $\mathrm{Xa}-10$ in rice (Oryza sativa) involves accumulation of a lignin-like substance in host tissues. Physiol. Mol. Plant Pathol. $38,39-55$.

Riedle-BAuer M., 1998. Activities of antioxidant enzymes in cucumber plants infected with Cucumber mosaic virus. Phyton. (Horn, Austria) 37, 251- 258.

Shukla H.S., Dubey P., Chaturvedi R.V., 1989. Antiviral properties of essential oils of Foeniculum vulgare and Pimpinella anisum L. Agronomie 9(3), 277-279.

Singh H.P., Kaur S., Batish D.R., Kohli R.K., 2014. Ferulic acid impairs rhizogenesis and root growth, and alters associated biochemical changes in mung bean (Vigna radiata) hypocotyls. J. Plant Interact. 9, 267-274.

Smith J.H.C., Benitez A., 1955. Chlorophylls analysis in plant materials. In: Modern Methods of Plant Analysis. vol. 4. K. Peach and M.V. Tracey (Eds), Springer-Verlag, Berlin, Germany, 142-196.

SoleCKA D., KaCPERSKa A., 2003. Phenylpropanoid deficiency affects the course of plant acclimation to cold. Physiol. Plant. 119, 253-262.

Wang F., Feng G., Chen K., 2009. Defense responses of harvested tomato fruit to burdock fructooligosaccharide, a novel potential elicitor. Postharv. Biol. Technol. 52, 110-116.

WAZIRI H.M.A., 2015. Plants as antiviral agents. J. Plant Pathol. Microbiol. 6, 254.

Xi D., Li J., Han C., Li D., Yu J., Zhou X., 2008. Complete nucleotide sequence of a new strain of Tobacco necrosis virus $A$ infecting soybean in China and infectivity of its full-length cDNA clone. Virus Genes 36, 259-266.

Zhao L., Chen Y., Wu K., Yan H., Hao X., Wu Y., 2017. Application of fatty acids as antiviral agents against Tobacco mosaic virus. Pest. Biochem. Physiol. 139, 87-91.

Zitikaité I., StaniUlis J., 2009. Isolation and characterization of Tobacco necrosis virus detected on some vegetable species. Biologija 55, 35-39.

Received May 26, 2018; accepted October 15, 2018 